\title{
Identification and Spatial Pattern of Kao Bay Bathymetry Based on UNCLOS
}

\author{
Yulius and H. L. Salim \\ Pusat Litbang Sumberdaya Laut dan Pesisir, Badan Litbang KP, KKP \\ Jalan Pasir Putih I Ancol Timur 14430 Jakarta - Indonesia Telp/Fax: +62 2164711654 \\ Corresponding E-mail : yulius.lpsdkp@gmail.com
}

\begin{abstract}
Kao Bay is located in the province of North Maluku between Regency of North Halmahera and West Halmahera. The study aims are to identify bay criteria according to UNCLOS and bathymetry based on Nautical Chart. The methods used in this study are the identification of the bay area under UNCLOS and spatial analysis using GIS software. The result shows that Kao Bay has a coast line length of $127.7 \mathrm{~km}$, a mouth bay cover line of $11.1 \mathrm{~km}$, total surface area of $964.38 \mathrm{~km}^{2}$, and total surface semi-circular bay cover area of $48.4 \mathrm{~km}^{2}$. The total surface area larger than the area of the semicircle bay cover area. It has been full compliance with the criteria required by UNCLOS. Spatial analysis, found that for the depth of water in Kao Bay can be divided into six classes, these are: (1) 0 - 100 meter with area of $964,38 \mathrm{~km}^{2}$, (2) 100 - 200 meter with area of 667.25 $\mathrm{km}^{2}$, (3) 200 - 300 meter with area of $556.95 \mathrm{~km}^{2}$, (4) 300 - 400 meter with area of $376.89 \mathrm{~km}^{2}$, (5) 400 - 500 meter with area of $202.44 \mathrm{~km}^{2}$, (6) $500-600$ meter with area of $2.22 \mathrm{~km}^{2}$.
\end{abstract}

Keywords : Bathymetry, Geographic Information System (GIS), Kao Bay, Toponymy, UNCLOS

\begin{abstract}
Abstrak
Teluk Kao merupakan sebuah teluk yang terletak di wilayah Provinsi Maluku Utara diantara Kabupaten Halmahera Utara dan Halmahera Barat. Penelitian ini bertujuan untuk mengidentifikasi kriteria teluk menurut UNCLOS dan batimetri perairan Teluk Kao dari peta laut. Metode yang digunakan dalam penelitian ini adalah pengidentifikasian teluk menurut UNCLOS dan analisis spasial yang menggunakan perangkat lunak Sistem Informasi Geografis. Berdasarkan hasil identifikasi, Teluk Kao memiliki garis pantai sepanjang 127,7 km, garis penutup teluk sepanjang 11,1 km dan luas Teluk Kao adalah sebesar $964,38 \mathrm{~km}^{2}$. Adapun luas setengah lingkaran penutup teluk adalah sebesar 48,4 km², sehingga dapat diketahui bahwa Teluk Kao masuk ke dalam kriteria area teluk menurut UNCLOS, yang mana luas Teluk Kao lebih besar dibandingkan luas setengah lingkaran penutup teluknya. Hasil analisis secara spasial, diperoleh bahwa untuk batimetri perairan Teluk Kao dapat dibagi menjadi enam kelas, yaitu: (1) 0 - 100 meter dengan areal seluas $964,38 \mathrm{~km}^{2}$, (2) 100 - 200 meter dengan areal seluas $667,25 \mathrm{~km}^{2}$, (3) 200 - 300 meter dengan areal seluas $556,95 \mathrm{~km}^{2}$, (4) 300 - 400 meter dengan areal seluas $376,89 \mathrm{~km}^{2}$, (5) 400 - 500 meter dengan areal seluas $202,44 \mathrm{~km}^{2}$, (6) 500 - 600 meter dengan areal seluas $2,22 \mathrm{~km}^{2}$.
\end{abstract}

Kata kunci : Batimetri, Sistem Informasi Geografis (SIG), Teluk Kao, Toponimi, UNCLOS

\section{Introduction}

Bay is a topographic features with distribution in a stretch of islands of the archipelago (Marine and Fisheries Research Institution, 2007). Indonesia is an archipelago with many bays and 341 bays are already named (Ramdhan, 2012). A region is called a bay if it meets the requirements from the United Nations Conventions on the Law Of the Sea (UNCLOS). UNCLOS is an international agreement which is resulted from the United Nations Conference on the Law of the Sea. Indonesia is one of the countries that adopts law that exist on UNCLOS through Law No. 17 of 1985 on Ratification of Convention on Law of the Sea, 1982. As a law state, giving a name to a bay should refer to the rules of UNCLOS since the convention is one of the sources of law (Bagir, 2006). In addition it is also strengthened with the establishment of the agency in the UN for naming geographic elements i.e UNGEGN (United Nation Groups of Expert s on Geographical Name). One of the elements of the natural geography is bay that must be studied and learned (Yulius et al., 2014).

A bay as an enclosed estuary has a strategic role as one of the ecological resources and environmental services (Ramdhan, 2012). Besides, the bay is also home to the activities of coastal communities, both economic and social (Marine and Fisheries Research Institution, 2007). According to Kusuma and 
Widjanarko (2007), that condition indicates that there are a lot of economic activities taken place in a bay, such as aquaculture, transportation and infrastructure which run the economy in that place. Understanding the definition of the bay is required in order to facilitate the identification both in the field and studies (Marine and Fisheries Research Institution, 2007). According to UNCLOS, it is considered as a bay if it is as large as, or larger than, that of the semi-circle whose diameter is a line drawn across the mouth of that indentation (United Nations, 1983).

Kao Bay is a bay located in the province of North Maluku between North Halmahera and West Halmahera. Kao Bay which is located in North Halmahera with the same administrative name has beautiful white sandy beach and island, but it also keeps the relics of World War II. This region consists of the Kao, Kao North, West Kao, Kao bay and Malifut Districts (DKP Halut Regency, 2008). From the history during World War II in 1942-1945, It is known that Kao was a base for thousands of Japanese soldiers. After Japan's defeat in the Pacific War, Japanese forced retreated to consolidate in Kao. Japan eventually put as many as 42,000 soldiers in Kao, while others which reached 20,000 were in the inner bay. Kao at that time was called as "Little Tokyo" or "The second Tokyo" (http://www.halmaherautara.com).

Bathymetric map has been used for several purposes, among others; for the boundary delimitations, marine scientific research, development of the region for aquaculture, marine tourism, shipping safety, exploration of marine resources and seabed, coastal engineering, marine modeling, determining shipping lanes and ports , etc. (Julius et al., 2011) .

This study aims to identify the criteria according to UNCLOS and bathymetry of Kao Bay with a scale of $1: 200,000$ with its range in hectare of Sea Maps data using Geographic Information System (GIS). The results are expected to support the utilization of Kao Bay for marine tourism, shipping safety, determining shipping lanes and ports, fishing and/or aquaculture or other uses .

\section{Research Method}

\section{a. Research Location}

This research is conducted in Kao Bay, North Maluku Province (Figure 1).

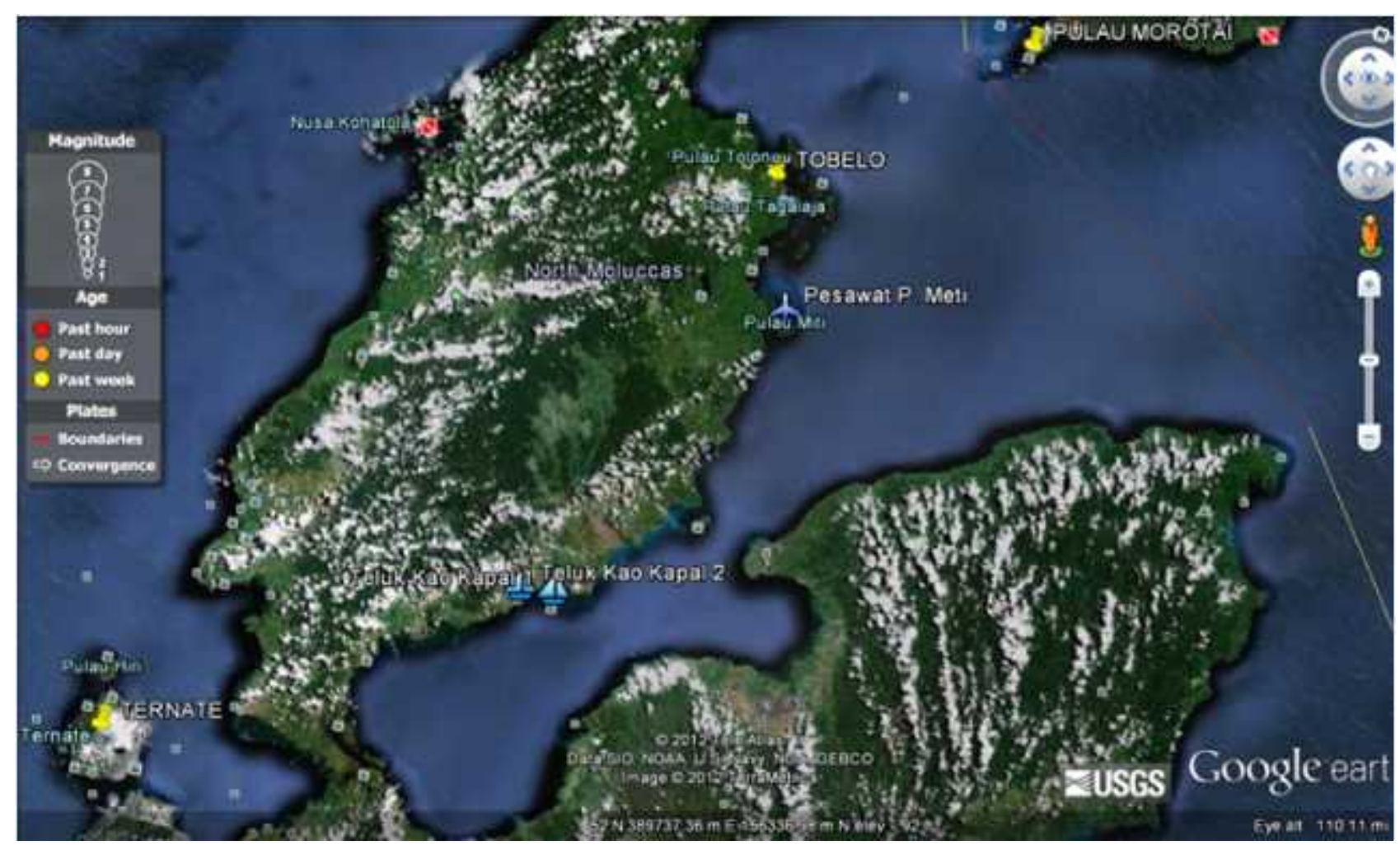

Figure 1. Map of research location (red square) (Source : Google Earth, 2012) 


\section{b. Data and Software}

The data which has been used is a Sea Map page 387, Halmahera Island - East Coast, Miti Island to Inggelang Cape, Kao Bay, Buli Gulf, with the accuracy of 200 meters and a scale of 1:200,000, Raster spatial data format, the Geographic Coordinate System, Datum Bessel -1841 (Department of Hydro Oceanography of TNI-AL (Indonesian Navy), 2004)

The software used to process the data consists of geographic information system which is equipped with image analysis extension for the visual interpretation, the shoreline digitization process and depth lines on the sea map, and the making of thematic maps.

\section{c. Diagram of Research Flow}

The series of making the identification and bathymetry spatial pattern of Kao Bay, in flowchart,

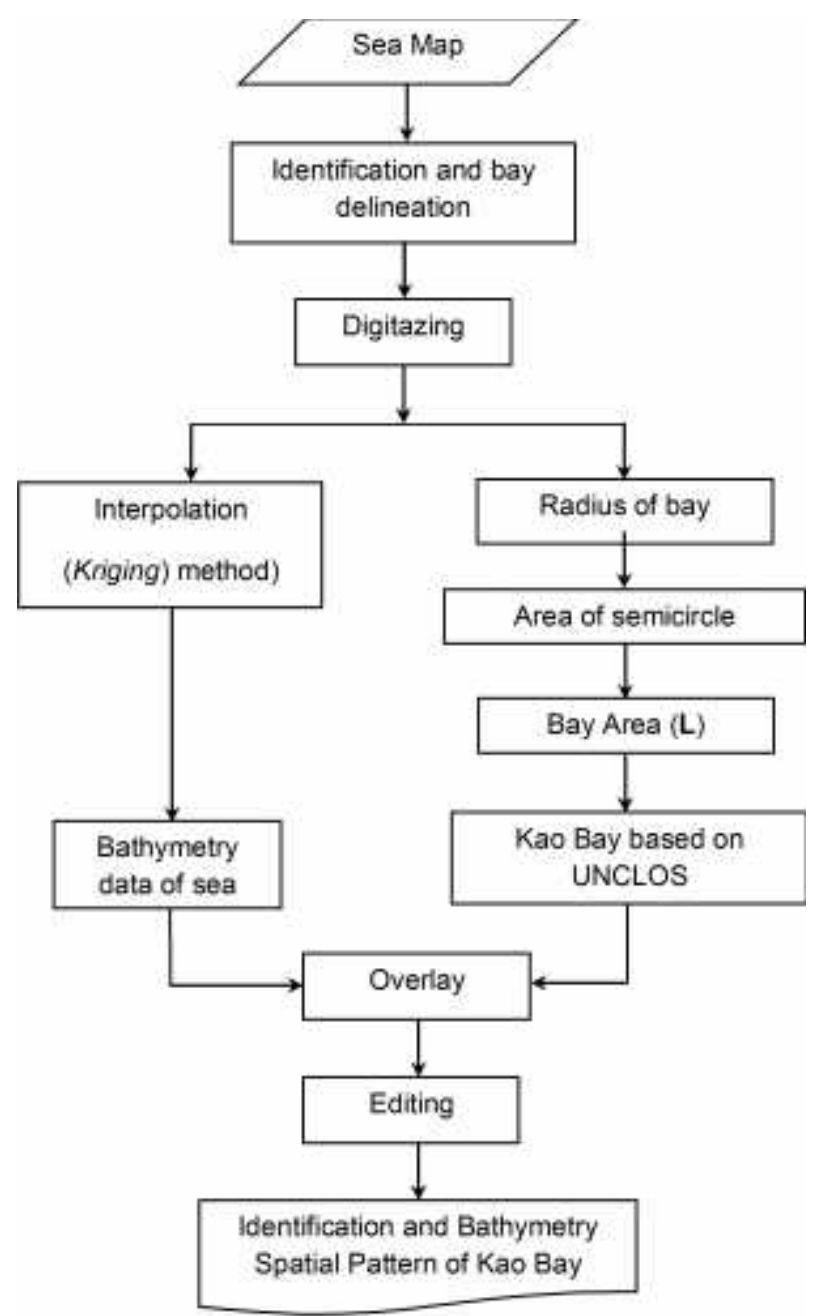

Figure 2. Flowchart of Identification and bathymetry spatial pattern of Kao Bay can be explained in several stages. First, by identifying and delineating the bay limit of sea map data and then performing digitization. The next stage is the determination of the bay according to UNCLOS in stages as follows; determining the radius of the bay mouth, counting the area of the semicircle, and calculating the area of the bay, and also performing bathymetric mapping Kao Gulf from the sea maps with kriging interpolation method. Then, UNCLOS and the interpolation results are overlayed. Next, the editing process of the results is performed which finally results in the identification and spatial patterns of bathymetry Kao Bay based on the UNCLOS and bathymetry classification based on modification classification of IHO 1998 (Canadian Hydrographic Service Fisheries and Oceans, 1998). Stages of the study are presented in Figure 2.

\section{d. Identification of Bay criteria based on UNCLOS}

To say that an object can be called a bay, the basic understanding of a bay and the withdrawal method of the closing line are based on UNCLOS III Article 10, 1982 (Kusumah and Widjanarko, 2007). According to Article 10, paragraph 2 of UNCLOS, a bay is a well-marked indentation whose penetration is in such proportion to the width of its mouth as to contain land-locked waters and constitute more than a mere curvature of the coast. An indentations shall not, however, be regarded as a bay unless its area is as large as, or larger than, that of the semi-circle whose diameter is a line drawn accross the mouth of that indentation (Figure 3).

According Kusumah and Widjanarko, 2007, a bay also has a proviso that if the distance between low water-marked at the natural entrance points of a bay does not exceed 24 nautical miles, the closing lines may be drawn between these two low-water lines and closed waters and therefore considered as inland waters (verse 4). If the distance exceeds 24 nautical miles, then a straight baseline drawn 24 nautical miles in length in the bay such that the closing of a maximum area of water that may be achieved by the long line (paragraph 5) (Figure 4).

\section{e. Kriging method}

Kriging method has several advantages. Largueche, (2006) in Siregar, et al., (2009) stated that as interpolator, kriging method combines the spatial correlations among the data, which it was not done by the classical statistical procedures. Kriging advantage compared to other 


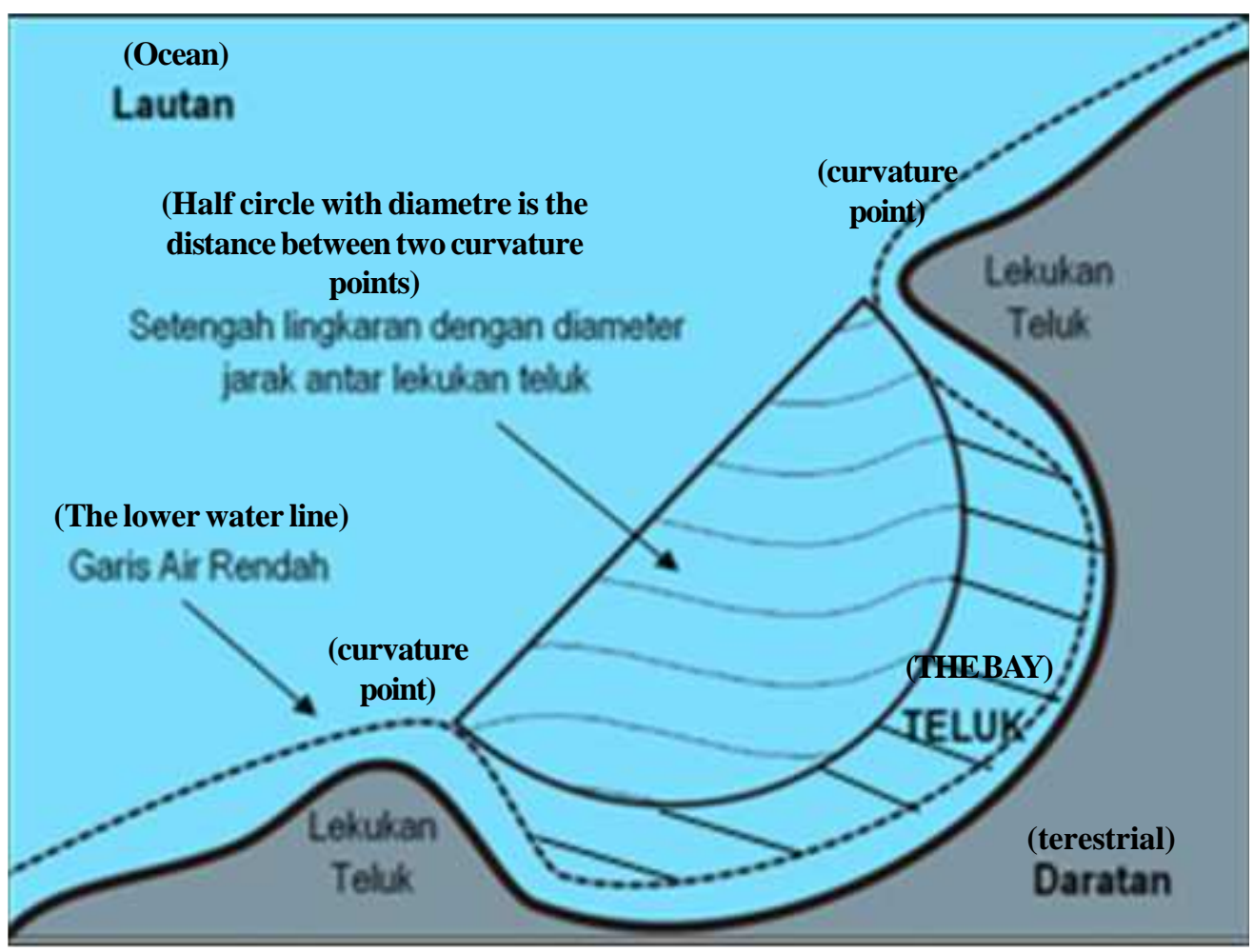

Figure 3. Criteria of Bay based on UNCLOS (Source: Ramdhan, 2012)
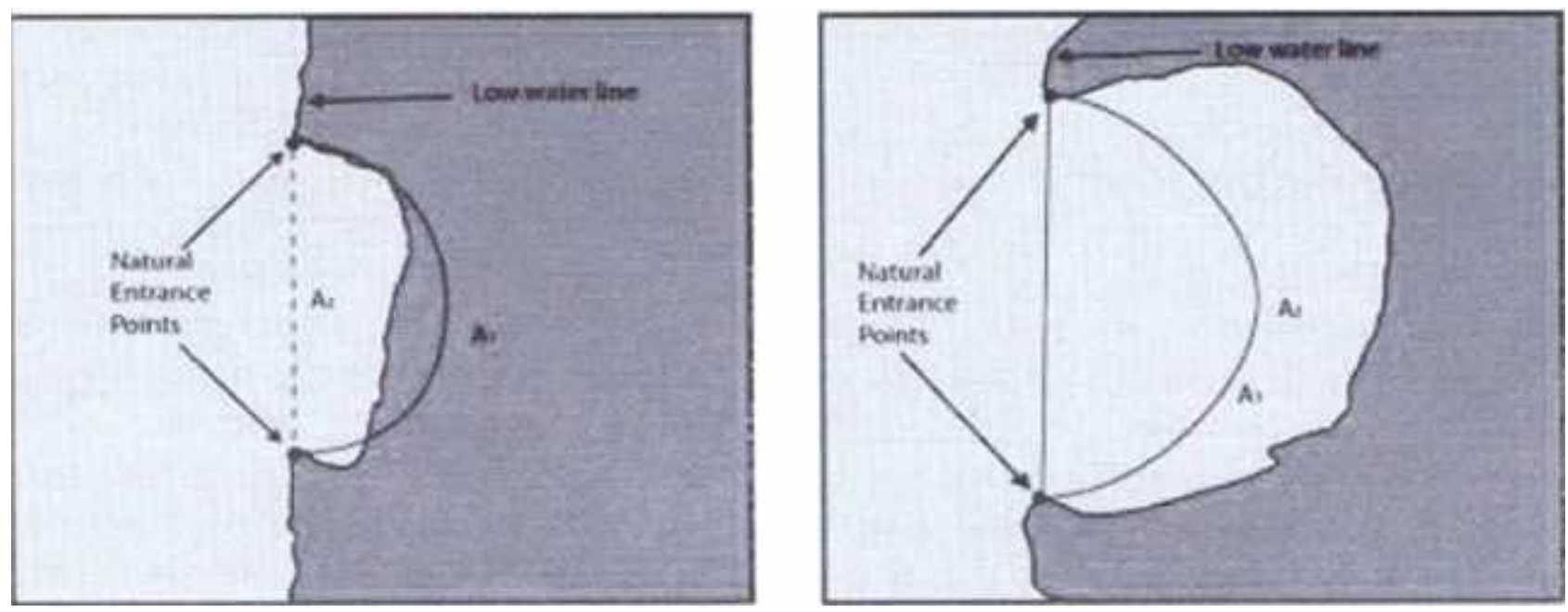

Figure 4. Article 10, Verse 4 UNCLOS: A bay as an inlad water, not included as a bay (left), included as a bay (right) (source: IHO, 2006 in Kusumah and Widjanarko, 2007)

Konturization techniques is its ability to quantify the variation of the estimated values so that the level of precision of the estimation can be figured. Siregar, et al., (2009) adds that the kriging method can still be used even though the spatial correlation was not found among the data. In an independent observation, kriging estimation process will be similar to the estimation using small squares regression analysis.

\section{Results and Discussion}

The calculation by using the Geographic Information System results in the dimension of Kao Bay. Kao Bay has a coastline of $127.7 \mathrm{~km}$, bay closing lines along $11.1 \mathrm{~km}$ and Kao Bay area of $964.38 \mathrm{~km}^{2}$. Since the area of semicircle bay cover is $48.4 \mathrm{~km}^{2}$, it can be concluded that Kao Bay is categorized as a bay area according to the criteria of UNCLOS since 
its area is larger than the area of the semicircle bay cover. These data are obtained by using the Map Sea issued by Dishidros with a scale of 1:200,000 which assuming an error rate of $1 \mathrm{~mm}$ and making the calculation above have an error margin of \pm 2 $\mathrm{km}$ (Figure 5).

From the Figure 5, it is shown that Kao Bay closing lines are taken from both sides of the cape which is the basic point. Cape point of Kao Bay closing lines which are in the Southwest is the Baleo Cape Point and Cape point of Kao Bay closing lines which are in the southeast is the Waisile cape point.

Based on marine map data which have been digitized and then processed and included in the interpolation process, the rough interpolation has produced some visual models both in 2-dimensions or 3-dimensions. For two-dimensional display, it is gained the depth contour lines on longitude and latitude which have been recorded as presented in Figure 6. While the display in three-dimensional perspective with blue gradient for the depth color can be seen in Figure 7.

Basic profile picture of the research location can be seen in Figure 9 which is a three-dimensional visualization from interpolation data of sea map.

Research location of $964.38 \mathrm{~km}^{2}$ has the depth up to 600 meters. Seabed topography at nearshore areas is sloping which it gradually turns into steep. Furthermore, seabed topography untill the outer island has the rough depth change which occurs in steep topography.

Based on the results of spatial analysis, the depth of the waters in the research location can be divided into six classes, namely: (1) 0-100 meters with an area of $964.38 \mathrm{~km}^{2}$, (2) 100-200 meters with an area of $667.25 \mathrm{~km}^{2}$, (3) 200-300 meters with an area of 556.95 $\mathrm{km}^{2}$, (4) 300-400 meters with an area of $376.89 \mathrm{~km}^{2}$, (5) 400-500 meters with an area of $202.44 \mathrm{~km}^{2},(6)$ $500-600$ meters with an area of $2.22 \mathrm{~km}^{2}$, as shown in Table 1.

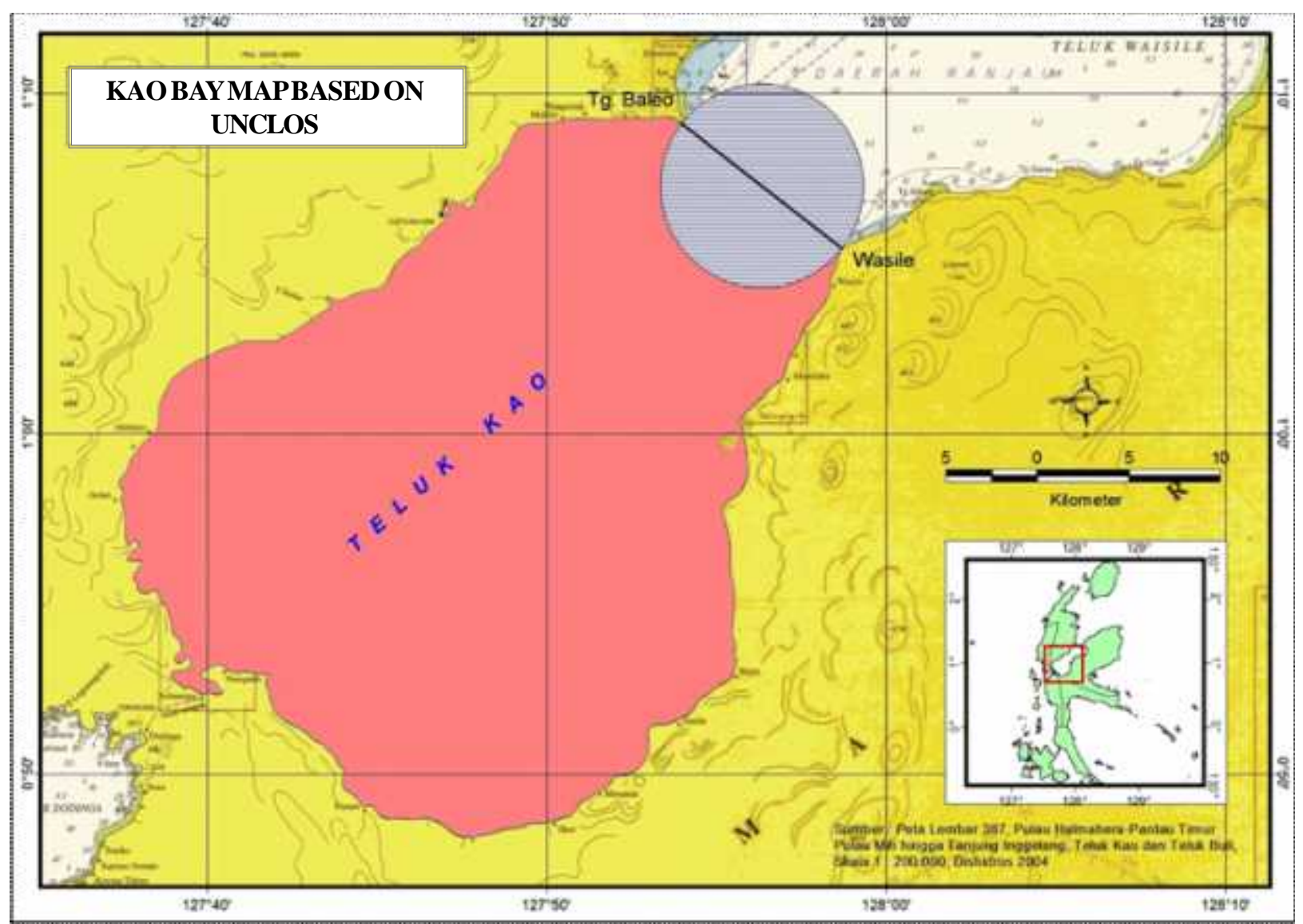

Figure 5. Identification of calculation of Kao Bay area based on criteria in article 10, UNCLOS 1982 


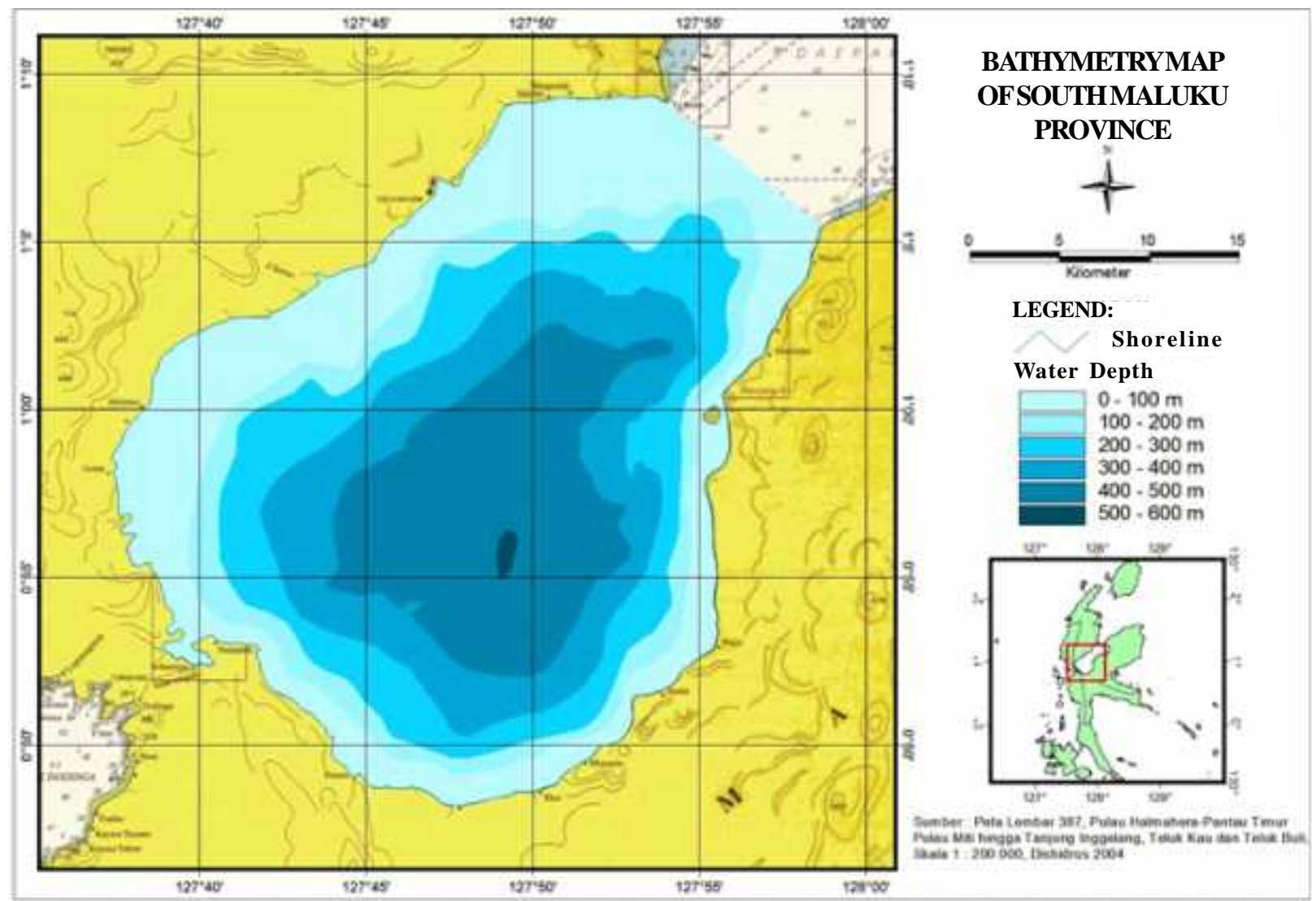

Figure 6. 2-D map of Bathymetry Contour in Kao Bay, South Maluku Province

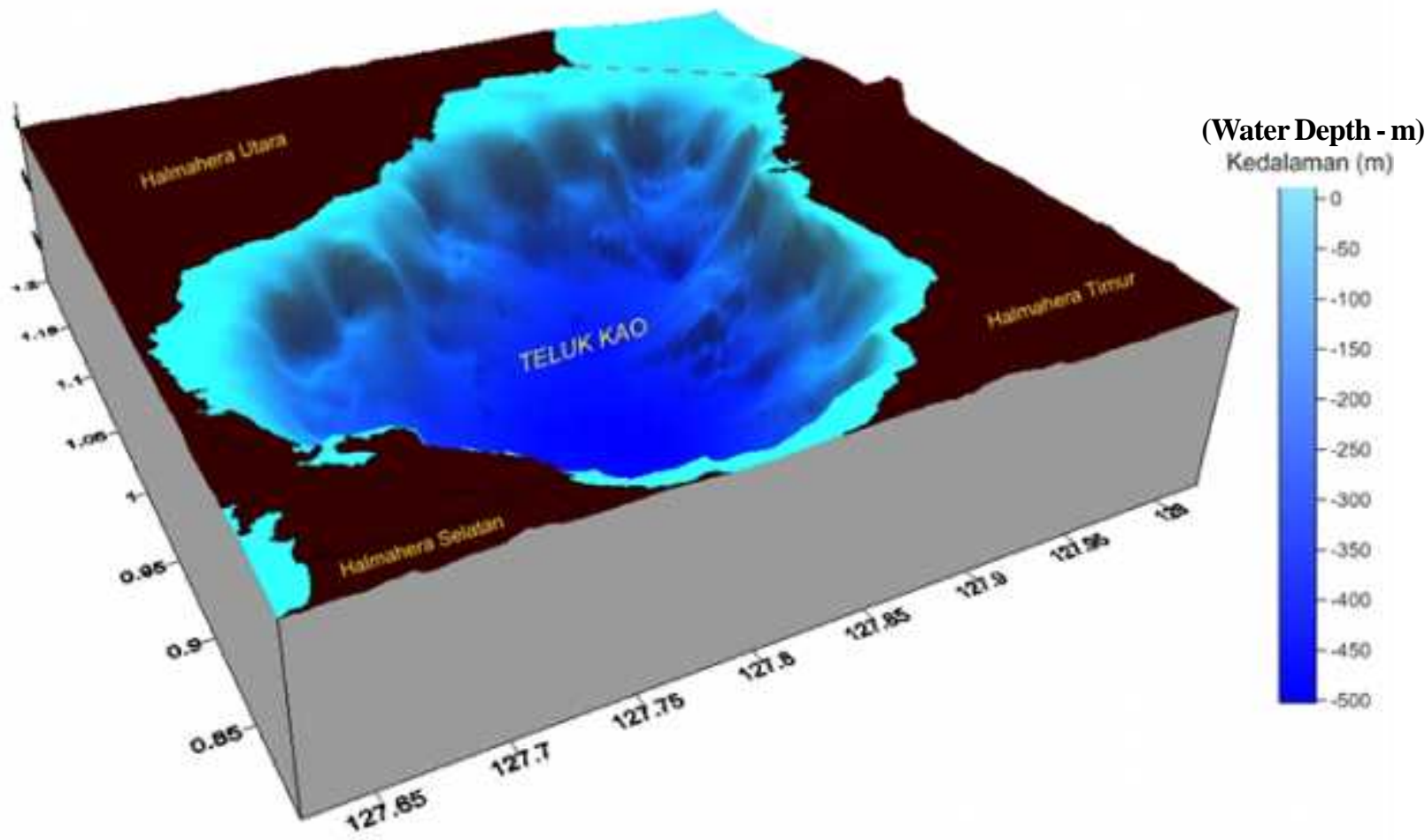

Figure 7. 3-D depth map of Kao Bay Bathymetry, North Maluku province 
Table 1. Area of bathymetry of water

\begin{tabular}{llcc}
\hline No & $\begin{array}{c}\text { Depth of water teritorial/ } \\
\text { Bathymetry }(\mathrm{m})\end{array}$ & Area $\left(\mathrm{km}^{2}\right)$ & Percentage $(\%)$ \\
\hline 1 & $0-100$ & 964.38 & 100.00 \\
2 & $100-200$ & 667.25 & 69.19 \\
3 & $200-300$ & 556.95 & 57.75 \\
4 & $300-400$ & 376.89 & 39.08 \\
5 & $400-500$ & 202.44 & 20.99 \\
6 & $500-600$ & 2.22 & 0.23 \\
\hline
\end{tabular}

\section{Conclusion}

Based on the identification result, it is found that Kao Bay has a coastline of $127.7 \mathrm{~km}$ with bay closing lines along $11.1 \mathrm{~km}$ and Kao Bay area of $964.38 \mathrm{~km}^{2}$. Furthermore, the semicircle bay cover is $48.4 \mathrm{~km}^{2}$ so that it can be sated that Kao Bay is included as the bay area according to the criteria of UNCLOS since its area is larger than the area of the semicircle bay cover.

Bathymetry waters in this research location can be divided into six classes, namely: (1) 0-100 meters with an area of $964.38 \mathrm{~km}^{2}$, (2) 100-200 meters with an area of $667.25 \mathrm{~km}^{2}$, (3) 200-300 meters with an area of $556.95 \mathrm{~km}^{2}$, (4) $300-400$ meters with an area of $376.89 \mathrm{~km}^{2}$, (5) 400-500 meters with an area of 202.44 $\mathrm{km}^{2}$ and (6) 500-600 meters with an area of 2, 22 $\mathrm{km}^{2}$.

\section{Acknowledgement}

The authors deliver their gratitude to the Research and Development Center of Marine and Coastal Resource (Puslitbang Sumberdaya Laut dan Pesisir/ Balitbang-KP) on funding of this research.

\section{References}

Canadian Hydrographic Service Fisheries and Oceans. 1998. Standard for Hydrographic Survey 2nd edition. Canada.

DKP Halut Regency, 2008. Executive Summary : Master Plan Arrangement of Integrated Coastal Zone Development in North Halmahera Regency, Tobelo. In Bahasa.

Hydrooceanography Agency, 2004. Nautical Chart sheet number 387, Halmahera Island - East Coast, Miti Island to Inggelang Cape, Kao Bay, Buli Bay, Indonesian Navy, Jakarta. In Bahasa.

Kusumah,G. and Widjanarko,E. 2007. Bay and Cape identification in Bungus Bay according to Maritime Topnymy Principle. Jurnal Segara:3(2):105-111. In Bahasa.

Manan,B. 2006. Constitusional Convension. Faculty of Law. UII Press, Yogyakarta. In Bahasa.

Marine and Fisheries Research Institution, 2007. Guide Book on Toponym Survey of Bay and Cape in Indonesia, Jakarta. In Bahasa.

Ramdhan,M.2012. The Criteria on Bay Determination according to United Nation Conventions on the LAW of the SEA - Case study at Kabung Bay Bungus Region in Padang City. Jurnal Ilmiah Geomatika: 18(2):3746. In Bahasa.

Siregar, V.P., and Selamat, M.B. 2009. Interpolator in Bathymetri Map Contour Making. Jurnal Ilmu dan Teknologi Kelautan Tropis: 1(1):39-47. In Bahasa. 
United Nations, 1983, The Law of the Sea - UN Convention on the Law of the Sea 1982, UN Publication No. E.83.V.5. New York, NY.

Yulius, Prihatno, H., and Suhelmi, I.R. 2011. Spatial Pattern of Bathymetry in Bungus Bay, Padang City. Proceeding of Annual National Scientific Meeting VII ISOI 2010:205-212. In Bahasa.

Yulius, Suhelmi, I.R., and Ramdhan, M. 2014. Island Identification at River Estuary Based on Toponymy (Case Study: River Estuary of Bulungan, Bulungan Regency, North Kalimantan Province). Jurnal Forum Geografi: 28(1):43-56. In Bahasa.

https://www.google.co.id/maps/@ 1.1281186,127.5258943,9z?hl=en, (accessed at 2012).

http://www.halmaherautara.com/kaom/panduan-perjalanan-di-wilayah-kao-\&- malifut\#.U89qkEAuc4c (accessed at April 1st 2013). 